\title{
Evaluation of risk factors and modern possibilities for prediction of preterm labour
}

\author{
A. O. Shevchenko*A-D, Yu. Ya. Krut ${ }^{\mathrm{E}, \mathrm{F}}$
}

Zaporizhzhia State Medical University, Ukraine

A - research concept and design; B - collection and/or assembly of data; C - data analysis and interpretation; D - writing the article;

$\mathrm{E}$ - critical revision of the article; $\mathrm{F}$ - final approval of the article

The aim is based on the comprehensive examination of pregnant women to determine the risk factors for preterm labor and develop criteria for its prediction.

Materials and methods. In a prospective opened study took part 63 patients at 22-34 weeks of gestation. The study was carried out on the basis of PI "Regional Perinatal Center" ZRC, which is the clinical base of the Department of Obstetrics and Gynecology, ZSMU. The average age of pregnant women was $27.1 \pm 0.8(\mathrm{M} \pm \mathrm{SD})$ years. Pregnant women were divided into two groups, depending on the gestation period course. Thus, group I included 44 pregnant women who had TPL (threatened preterm labor), and group II - 19 patients with normal course of pregnancy. In the first day, body mass index was determined and laboratory examinations (progesterone, insulin and cortisol level) were performed.

Results. According to the ROC analysis, we obtained the following distribution points: the age of pregnant women over 35 years (sensitivity $33.3 \%$, specificity $96.1 \%$ ), the area under the ROC curve of 0.542 ( $95 \% \mathrm{Cl} 0.411-0.668, \mathrm{P}=0.6953$ ); body mass index (BMI) $\leq 22.95 \mathrm{~kg} / \mathrm{m}^{2}$ (sensitivity $66.7 \%$, specificity $84.3 \%$ ), the area under the ROC curve $0.694(95 \% \mathrm{Cl} 0.566-0.804$, $\mathrm{P}=0.01)$; insulin $>31.36 \mu \mathrm{Me} / \mathrm{ml}$ (sensitivity $41.7 \%$, specificity $90.2 \%)$, the area under the ROC curve $0.505(95 \% \mathrm{Cl} 0.376-0.633$, $\mathrm{P}=0.96)$; cortisol $\leq 609.7 \mathrm{ng} / \mathrm{ml}$ ( $75 \%$ sensitivity, $55 \%$ specificity), the area under the ROC curve of $0.694(95 \% \mathrm{Cl} 0.518-0.765$, $\mathrm{P}=0.07$ ); progesterone $<247.8 \mathrm{ng} / \mathrm{ml}$ (sensitivity $41.7 \%$, specificity $88.2 \%$ ), the area under the ROC curve $0.579(95 \% \mathrm{Cl}$ $0.448-0.703, P=0.4)$.

Conclusions. The results of the conducted research indicate that multivariate logistic regression analysis allows determining the risk factors of preterm labor. Among the established prognostic markers for spontaneous preterm birth, the most comprehensive information is the complex assessment of age, BMl and hormonal profile. The findings suggest that dependent risk factors for preterm birth include: the level of progesterone lower than $139.5 \mathrm{ng} / \mathrm{ml}$, cortisol less than $577.9 \mathrm{ng} / \mathrm{ml}$, BMl less than $24 \mathrm{~kg} / \mathrm{m}^{2}$ and maternal age of over 25 years. Independent factors should include the maternal age of over 35 years, the level of insulin above $31.36 \mathrm{ng} / \mathrm{ml}$ and progesterone less than $247.8 \mathrm{ng} / \mathrm{ml}$. Considering the study results, high specificity and sensitivity of the proposed multivariate models, it would be appropriate to include measurements of progesterone, insulin and cortisol levels in the standard examination complex for pregnant women from 22 to 34 weeks of gestation. It will enable the identification of a risk group for preterm labor and implementation of timely prevention.

\section{Оцінювання факторів ризику та сучасні можливості прогнозування передчасних пологів}

\section{А. О. Шевченко, Ю. Я. Круть}

Мета роботи - на підставі комплексного обстеження вагітних встановити фактори ризику передчасних пологів і розробити критерії їх прогнозування.

Матеріали та методи. У проспективному відкритому дослідженні взяли участь 63 пацієнтки в терміні вагітності 22-34 тижні. Дослідження виконали на базі КЗ «Обласний перинатальний центр» ЗОР, що є клінічною базою кафедри акушерства та гінекології ЗДМУ. Середній вік вагітних - 27,1 \pm 0,8 (M \pm SD) року. Вагітних поділили на дві групи залежно від перебігу гестаційного періоду. У I групу увійшли 44 вагітні, які мали загрозу передчасних пологів, а в II - 19 пацієнток із нормальним перебігом вагітності. Протягом першої доби всім жінкам встановили індекс маси тіла (IMT) і здійснили лабораторне обстеження (визначення прогестерону, інсуліну та кортизолу).

Результати. У результаті ROC-аналізу отримали такі точки розподілу: вік вагітних понад 35 років (чутливість - 33,3 \%, специфічність - 96,1 \%), площа під кривою - 0,542 (95 \% ДІ 0,411-0,668; p = 0,6593); індекс маси тіла (IMT) $\leq 22,95$ кг $/ \mathrm{M}^{2}$ (чутливість - 66,7 \%, специфічність - 84,3\%), площа під кривою - 0,694 (95\% ДІ 0,566-0,804; p= 0,01); інсулін >31,36 мкME/мл (чутливість - 41,7 \%, специфрічність - 90,2 \%), площа під кривою - 0,505 (95 \% ДІ 0,376-0,633; p = 0,96); кортизол $\leq 609,7$ нг/мл (чутливість - $75 \%$, специфрічність - $55 \%$ ), площа під кривою - 0,649 (95\% ДІ 0,518-0,765; p = 0,07); прогестерон <247,8 нг/мл (чутливість - 41,7 \%, специфрічність - 88,2 \%), площа під кривою - 0,579 (95 \% ДІ 0,448-0,703; $p=0,4)$.

Висновки. Результати дослідження свідчать, що багатофракторний логістичний регресійний аналіз дає можливість визначити фактори ризику передчасних пологів. Серед встановлених прогностичних маркерів щодо спонтанного розвитку передчасних пологів найбільш інформативним є комплексне оцінювання віку, IMT і гормонального профілю. Встановлені дані свідчать, що залежними факторами ризику передчасних пологів $є$ рівень прогестерону менше ніж 139,5 нг/мл, кортизолу менше ніж 577,9 нг/мл, ІІМТ менше за 24 кг/м² і вік вагітної понад 25 років. Незалежні фактори: вік вагітних понад 35 років, рівень інсуліну понад 31,36 мкМЕ/мл, рівень прогестерону менше ніж 247,8 нг/мл. Враховуючи
Key words: preterm birth, progesterone, insulin, cortisol, prognosis.

\section{Zaporozhye} medical journal 2019; 21 (6), 759-763 DOl: 10.14739/2310-1210. 2019.6.186500

*E-mail: shevchenkoaa0202@ gmail.com

Ключові слова: передчасні пологи, прогестерон, інсулін, кортизол, прогнозування.

Запорізький медичний журнал. - 2019. T. 21, № 6(117). C. 759-763 
результати дослідження, високу специфічність і чутливість запропонованих мультиваріантних моделей, вагітним у терміні 22-34 тижні доцільно в комплекс стандартного обстеження включати визначення рівня прогестерону, інсуліну, кортизолу, що дає змогу виявити групу ризику щодо розвитку передчасних пологів та своєчасно вжити профрілактичних заходів.

Киючевые слова: преждевременные роды, прогестерон, инсулин, кортизол, прогнозирование.

Запорожский медицинский журнал. - 2019. T. 21, № 6(117). C. $759-763$

\section{Оценка факторов риска и современные возможности прогнозирования преждевременных родов}

\section{А. А. Шевченко, Ю. Я. Круть}

Цель работы - на основании комплексного обследования беременных определить фракторы риска преждевременных родов и разработать критерии их прогнозирования.

Материалы и методы. В проспективном открытом исследовании приняли участие 63 пациентки в сроке беременности 22-34 недели. Исследование выполнено на базе КУ «Областной перинатальный центр» 3ОС, который является клинической базой кафедры акушерства и гинекологии ЗГМУ. Средний возраст беременных составил 27,1 \pm 0,8 (M \pm SD) года. Беременных поделили на две группы в зависимости от течения гестационного периода. В I группу вошли 44 беременные с угрозой преждевременных родов, а во II - 19 пациенток с нормальным течением беременности. В первые сутки у всех женщин определили индекс массы тела (ИМТ) и выполнили лабораторное обследование (определение прогестерона, инсулина и кортизола).

Результаты. В результате ROC-анализа получены такие точки распределения: возраст беременных старше 35 лет (чувствительность - 33,3 \%, специфичность - 96,1 \%), площадь под ROC кривой - 0,542 (95 \% ДИ 0,411-0,668; p = 0,6593); индекс массы тела (ИМТ) $\leq 22,95$ кг/м² (чувствительность - 66,7 \%, специфичность - 84,3 \%), площадь под ROC кривой 0,694 (95 \% ДИ 0,566-0,804; p = 0,01); инсулин >31,36 мкМЕ/мл (чувствительность - 41,7 \%, специфичность - 90,2 \%), площадь под ROC кривой - 0,505 (95 \% ДИ 0,376-0,633; p = 0,96); кортизол $\leq 609,7$ нг/мл (чувствительность - 75 \%, специфичность - 55 \%), площадь под ROC кривой - 0,649 (95 \% ДИ 0,518-0,765; р = 0,07); прогестерон <247,8 нг/мл (чувствительность - 41,7 \%, специфичность - 88,2 \%), площадь под ROC кривой - 0,579 (95 \% ДИ 0,448-0,703; p = 0,4).

Выводы. Результаты свидетельствуют, что многофакторный логистический регрессионный анализ позволяет определить факторы риска преждевременных родов. Среди установленных прогностических маркеров спонтанного развития преждевременных родов наиболее информативной является комплексная оценка возраста, ИМТ и гормонального профиля. Установленные данные показали, что к зависимым факторам риска преждевременных родов относятся уровень прогестерона меньше 139,5 нг/мл, кортизола меньше 577,9 нг/мл, ИМТ меньше 24 кг/м² и возраст беременной более 25 лет. К независимым факторам следует отнести возраст беременных старше 35 лет, уровень инсулина более 31,36 мкМЕ/мл и уровень прогестерона меньше 247,8 нг/мл. Учитывая результаты исследования, высокую специфичность и чувствительность предложенных мультивариантных моделей, беременным в сроке 22-34 недели целесообразно в комплекс стандартного обследования включать определение уровня прогестерона, инсулина и кортизола, что позволит установить группу риска по развитию преждевременных родов и своевременно провести профилактические мероприятия.

For many years, premature delivery (PD) remains one of the main problems of modern practical obstetrics due to high rates of reproductive loss, perinatal morbidity and mortality in preterm infants. Today, positive changes in this area have been achieved through a set of measures within the framework of the National Programs, regionalization of perinatal care and continuous improvement of the conditions for children with a small and extremely low body weight at birth. However, the data from the State Program for "Reproductive Health of the Nation" for the period up to 2018 indicate that direct reproductive losses from PD make up 36-40 thousand unborn wanted children annually and do not have a tendency to decrease, despite the high potential of obstetricians in the implementation of numerous and highly effective diagnostic methods and treatment regimens for pregnancy maintenance. The frequency of $\mathrm{PD}$ remains high and ranges between $10-12 \%$ and $20-25 \%$ of the total number of pregnancies [1,2]. More than 30-40\% of perinatal pathology and mortality cases are associated or predisposed to PD [3].

Given the fact that PD is based on both polyetiologic factors and polypathogenetic mechanisms of development, at the present stage, it is considered not as an independent nosological entity, but as a syndrome [4]. PD syndrome covers a combination of processes caused by fibronectin assembly, changes in the cervical length, activation of infection in a pregnant woman, proinflammatory cytokines production in the amniotic fluid, and diseases of the newborn associated with an intrauterine infection [5].

The frequency of preterm birth varies in different regions of the world, for example, in the United States, PD rates are from $12 \%$ to $13 \%$, while in Europe and other developed countries, official rates range from $5 \%$ to $9 \%[6,7]$. It should be noted that during the last decade in industrialized countries, the rate of PD is increasing, for example, in the USA this indicator has increased from $9.5 \%$ to $12.8 \%$ (25\%) [7], despite the fact that specialists and scientists have obtained up-to-date knowledge about risk factors and mechanisms of PD development over the last years, as well as a number of social and medical interventions have been developed to reduce the rate of preterm labor [8].

Overall proportion of premature birth in the structure of perinatal mortality is about $75 \%$ and in the structure of long-term morbidity in children - more than $50 \%$ and it is the biggest problem [9]. In addition, most of premature children have an increased risk of developing neurological, respiratory and gastro-intestinal violations [9].

In fact, there are two reasons for inability to reduce the frequency of PD: the lack of both necessary examinations to identify women at high risk and effective measures to prevent these complications. Current conditions dictate the need to find new methods for predicting PD, as well as the use of new more effective methods of pregnancy maintenance. 


\section{The aim}

The aim is based on the comprehensive examination of pregnant women to determine the risk factors for preterm labor and develop criteria for its prediction.

\section{Materials and methods}

In a prospective open study, 63 patients at 22-34 weeks of gestation were included. Pregnant women were involved in the study after signing an informed consent. The study was carried out on the basis of PI "Zaporozhzhia Regional Perinatal Center", which is the clinical base for the Department of Obstetrics and Gynecology, ZSMU (the head of the Department - MD, PhD, DSc, Professor Yu. Ya. Krut). The average age of the pregnant women was $27.1 \pm 0.8$ $(\mathrm{M} \pm \mathrm{SD}$ ) years. The pregnant women were divided into two groups, depending on the gestation period course. Thus, group I included 44 pregnant women who had threatened preterm labor (TPL), and group II-19 patients with a normal course of pregnancy.

The exclusion criteria were severe somatic diseases. Every pregnant woman was interviewed to determine whether additional methods of examination would be appropriate and gave consent for their performance. The study met the modern moral and ethical standard requirements regarding the $\mathrm{ICH} / \mathrm{GCP}$ Guidelines, the Helsinki Declaration of 1964, the Council of Europe Conference on Human Rights and Biomedicine, as well as the provisions of the legislative acts of Ukraine.

On the first day, all women were laboratory examined (determination of progesterone, insulin and cortisol) and body mass index (BMI) was calculated.

Statistical processing of materials was carried out using the packages of programs Statistica 6.0 (StatSoft, USA) and MedCalc. The normality of quantitative characteristics distribution was checked with the Shapiro-Wilk test. The method of binary logistic regression analysis was used to determine the predictors of TPL. Factors that had a probable predictive value in one factor analysis were included in the multivariate model by the inverse step-by-step method for the determination of independent predictors. The data were presented as odds ratio and confidence intervals. Cut-off values of the quantitative indicators included in a multivariate logistic regression model were determined using ROC analysis. All statistical tests were two-sided and $P$ values $<0.05$ were considered statistically significant.

\section{Results}

Pregnant women with TPL accounted for $69.8 \%$ (44 out of 63 pregnant women) of the total number of patients involved in the study. For 12 women, pregnancy ended with preterm birth, accounting for $19.1 \%$ of the total. Most pregnant women $(80.9 \%)$ gave birth to full-term neonates.

According to the study results, pregnant women with TPL had a $57 \%(P<0.05)$ longer hospital stay after giving birth in comparison to women with normal pregnancy course ( $6.90 \pm 1.27$ days versus $3.70 \pm 0.33$ days). It was due to PD and, in some cases, the need for special medical care for preterm infants and resuscitation measures. In the structure of diseases in preterm infants, the leading ones were: hypoxic-ischemic injury of the central nervous system with inhibition syndrome, neonatal jaundice, respiratory distress syndrome, predominantly Type I, intraventricular cerebral hemorrhages and retinopathy of prematurity. Two children had a congenital heart disease as an intraventricular septum defect and an atrial septum defect, 2 children had neonatal jaundice.

In order to find out the factors that influence the course of pregnancy and increase the risk of PD, we have conducted an analysis of the results from the monitoring of 63 pregnant women who were observed in the PI "Zaporizhzhia Perinatal Center". Logistic regression analysis was used to determine the cut-off value of quantitative indicators that increase the risk of PD, to construct univariate and multivariate models and to identify dependent and independent risk factors for the spontaneous appearance of clinical symptoms and prematurity.

In the ROC analysis, we obtained the following distribution points (Table 1): the age of pregnant women over 35 years (sensitivity $33.3 \%$, specificity $96.1 \%$ ), the area under the ROC curve $0.542(95 \% \mathrm{Cl} 0.411-0.668, \mathrm{P}=0.6593)$; $\mathrm{BMI} \leq 22.95 \mathrm{~kg} / \mathrm{m}^{2}$ (sensitivity $66.7 \%$, specificity $84.3 \%$ ), the area under the ROC curve 0.694 (95\% Cl 0.566-0.804, $\mathrm{P}=0.01$ ); insulin $>31.36 \mu \mathrm{Me} / \mathrm{ml}$ (sensitivity $41.7 \%$, specificity $90.2 \%)$, the area under the ROC curve $0.505(95 \% \mathrm{Cl}$ $0.376-0.633, P=0.96)$; cortisol $\leq 609.7 \mathrm{ng} / \mathrm{ml}$ (75\% sensitivity, $55 \%$ specificity), the area under the ROC curve 0.694 (95\% Cl 0.518-0.765, P = 0.07); progesterone <247.8 ng/ml (sensitivity $41.7 \%$, specificity $88.2 \%$ ), the area under the ROC curve 0.579 (95\% Cl 0.448-0.703, $\mathrm{P}=0.4$ ).

These factors have been identified as the potential risk predictors for PD using regression logistic analysis. Table 2 shows the data of the univariate regression analysis.

Consequently, according to the univariate model (Table 2), the following indicators were found to be dependent risk factors for PD: maternal $>35$ years significantly increased the risk of PD in 12.25 times $(95 \% \mathrm{Cl} 1.91-78.27$; $P=0.008)$; the risk of $P D$ was also 10.75 times increased in BMl less than $22.95 \mathrm{~kg} / \mathrm{m}^{2}(95 \% \mathrm{Cl} 2.60-44.37, \mathrm{P}=0.001)$, the insulin level above $31.36 \mu \mathrm{M} / \mathrm{ml}$ significantly increased the risk of $\mathrm{PD}$ in 6,65 times $(95 \% \mathrm{Cl}$ 1,507-28,659; $P=0.01)$.

At cortisol levels $\leq 609.7 \mathrm{ng} / \mathrm{ml}$, PD was 3.65 times $(95 \% \mathrm{Cl} 1.50-28.65 ; \mathrm{P}=0.01)$ increased. The literary data indicate that the fetus can generate signaling factors that activate the labor activity itself. Hypothalamic-pituitary-adrenal theory is represented as one of these theories. Preparation for labor begins with the fetal adrenal cortex functional activation, which are responsible for the synthesis of major steroids - dehydroepiandrosterone and cortisol [10].

The risk of PD also depends on the level of progesterone, which was convincingly proved by the logistic regression analysis in our study. If progesterone was less than $247.8 \mathrm{ng} / \mathrm{ml}$, the risk of PD was 5.36 times $(95 \% \mathrm{Cl}$ 1.280-22.369; $P=0.02$ ) increased. Progesterone plays an important role in the central and peripheral nervous system regeneration manifesting in multifaceted effects, including soothing, anxiolytic and antidepressant effects at high concentrations, and vice versa, at low levels - anxiety and fear [11-13].

We have constructed three multivariate models (Table 3) with the logistic regression analysis. According 
Table 1. Distribution point by the ROC analysis for the risk of premature birth

\begin{tabular}{|c|c|c|c|c|c|c|}
\hline Indicator & Area under ROC curve (AUC) & $95 \% \mathrm{Cl}$ & Significance level, p & Distribution point & Sensitivity, \% & Specificity, \% \\
\hline Age, years & 0.542 & $0.411-0.668$ & 0.659 & $>35$ & 33.3 & 96.1 \\
\hline $\mathrm{BMI}, \mathrm{kg} / \mathrm{m}^{2}$ & 0.694 & $0.566-0.804$ & 0.011 & $\leq 22.95$ & 66.7 & 84.3 \\
\hline Insulin, $\mu \mathrm{M} / \mathrm{ml}$ & 0.505 & $0.376-0.633$ & 0.958 & $>31.36$ & 41.7 & 90.2 \\
\hline Cortisol, ng / ml & 0.649 & $0.518-0.765$ & 0.07 & $\leq 609.7$ & 75.0 & 54.9 \\
\hline Progesterone, ng/ml & 0.579 & $0.448-0.703$ & 0.403 & $<247.8$ & 41.7 & 88.2 \\
\hline
\end{tabular}

Table 2. Univariate model of the risk of premature delivery

\begin{tabular}{l|l|l|l}
\multirow{2}{*}{ Indicator, units } & Univariate model & \multicolumn{2}{l}{} \\
\cline { 2 - 4 } & Odds Ratio, OR & Significance level, P & 95\% Confidence interval, Cl \\
\hline Age, years & 12.25 & 0.008 & $1.91-78.27$ \\
\hline Insulin, $\mu \mathrm{Me} / \mathrm{mg}$ & 6.57 & 0.01 & $1.50-28.65$ \\
\hline Cortisol, $\mathrm{ng} / \mathrm{ml}$ & 3.65 & 0.073 & $0.08-15.08$ \\
\hline Progesterone, $\mathrm{ng} / \mathrm{ml}$ & 5.35 & 0.020 & $1.28-22.36$ \\
\hline BMl, $\mathrm{kg} / \mathrm{m}^{2}$ & 10.75 & 0.001 & $2.60-44.37$ \\
\hline
\end{tabular}

Table 3. Multivariate models of threatened preterm labor

\begin{tabular}{|c|c|c|c|c|c|c|c|c|c|}
\hline \multirow[t]{2}{*}{ Indicator, units } & \multicolumn{3}{|l|}{ Model 1} & \multicolumn{3}{|l|}{ Model 2} & \multicolumn{3}{|l|}{ Model 3} \\
\hline & $\begin{array}{l}\text { Odds ratio, } \\
\text { OR }\end{array}$ & $\begin{array}{l}\text { Significance } \\
\text { level, } \mathrm{P}\end{array}$ & $\begin{array}{l}95 \% \text { Confidence } \\
\text { interval, CI }\end{array}$ & $\begin{array}{l}\text { Odds ratio, } \\
\text { OR }\end{array}$ & $\begin{array}{l}\text { Significance } \\
\text { level, } P\end{array}$ & $\begin{array}{l}95 \% \text { Confidence } \\
\text { interval, } \mathrm{Cl}\end{array}$ & $\begin{array}{l}\text { Odds ratio, } \\
\text { OR }\end{array}$ & $\begin{array}{l}\text { Significance } \\
\text { level, } \mathrm{P}\end{array}$ & $\begin{array}{l}\text { 95\% Confidence } \\
\text { interval, Cl }\end{array}$ \\
\hline Age, years & 23.87 & 0.007 & $2.37-240.45$ & 100.95 & 0.002 & $5.42-1877.17$ & 65.12 & 0.006 & $3.39-1249.92$ \\
\hline Insulin, $\mu$ Me/mg & 10.28 & 0.02 & $1.45-72.87$ & & & & 12.23 & 0.04 & $1.10-135.69$ \\
\hline Cortisol, ng/ml & & & & 10.25 & 0.02 & $1.38-76.16$ & & & \\
\hline Progesterone, $\mathrm{ng} / \mathrm{ml}$ & 11.81 & 0.01 & $1.77-78.59$ & & & & & & \\
\hline $\mathrm{BMl}, \mathrm{kg} / \mathrm{m}^{2}$ & & & & 56.73 & 0.0009 & $5.23-615.17$ & 53.82 & 0.002 & 4.19-689.89 \\
\hline
\end{tabular}

to the first model, independent risk factors of PD were the following: maternal age over 35 years, serum insulin $>31.36 \mathrm{ng} / \mathrm{ml}$ and progesterone $<247.8 \mathrm{ng} / \mathrm{ml}$.

The combination of these factors significantly increased the odds ratio of PD in comparison with the influence of a particular factor in the univariate model. Thus, in the first multivariate model, maternal age over 35 years increased the risk of $P D$ in 29.3 times $(P<0.01)$, the level of insulin above 31.36 increased the odds ratio $(O R)$ in 10.3 times $(P=0.01)$ and progesterone level less than $247.8 \mathrm{ng} / \mathrm{ml}$ increased $O R$ in 11.8 times $(P=0.01)$.

The second model combined such independent risk factors as BMI, age and cortisol level. According to this model, the age proved to be a very powerful factor that the OR was 100 times $(P<0.01)$ increased, maternal body weight deficiency 56 times $(P<0.01)$ increased the OR and the cortisol level less than $609.7 \mathrm{ng} / \mathrm{ml}$ - in 10 times $(P=0.02)$.

The third model also combined BMI, age and insulin content. According to our data, the risk of PD was 65 times $(P<0.01)$ increased in maternal age over 35 years, 54 times $(P<0.01)$ - in BMl less than $22.96 \mathrm{~kg} / \mathrm{m}^{2}, 12$ times $(P=0.04)$ in insulin level above $31.36 \mu \mathrm{Me} / \mathrm{mg}$.

PD can be caused by a variety of factors, including infections, vascular lesions, uterine contractions, violation of mechanisms of allogeneic recognition, stress and other pathological processes [14,15].

It is known that increased activity of endogenous progesterone is required for normal pregnancy development as it can directly reduce the risk of PD due to endocrine and anti-inflammatory mechanisms. In addition, it has been shown that the level of endogenous progesterone withdrawal is involved in the onset of labor. It was followed by numerous studies on the evaluation of exogenous progesterone efficacy for PD prevention.

There are a number of recognized risk factors for $\mathrm{PD}$, including $\mathrm{PD}$ in the anamnesis, a short cervix according to ultrasound data in the second trimester of pregnancy, and a high concentration of cervicovaginal fetal fibronectin. The cervical length according to ultrasound data is a powerful and informative prognostic marker for PD, even more significant than the presence of PD in the anamnesis $[16,17]$.

\section{Discussion}

So, according to our data, the dependent factors for PD include:

- progesterone less than $139.5 \mathrm{ng} / \mathrm{ml}$ increases the OR in 8.23 times $(95 \% \mathrm{Cl} 1.06-63.94 ; \mathrm{P}=0.043)$;

- cortisol less than $577.9 \mathrm{ng} / \mathrm{ml}$ increases the OR in 10.6 times $(95 \% \mathrm{Cl}$ 1.93-57.68; $\mathrm{P}=0.006)$;

-BMl less than $24 \mathrm{~kg} / \mathrm{m}^{2}$ increases the OR in 12.4 times (95\% Cl, 1.89-81.14, P = 0.008);

- age more than 25 years increases the OR in 4.48 times $(95 \% \mathrm{Cl}$ 1.002-20.06, $\mathrm{P}=0.049)$.

Among the independent factors for $P D$ are:

- age over 35 years increases the risk in 29.3 times $(P=0.007)$;

- the level of insulin over $31,36 \mu \mathrm{Me} / \mathrm{mg}$ increases the OR in 10.3 times $(P=0,01)$;

- the level of progesterone less than $247.8 \mathrm{ng} / \mathrm{ml}$ increases $O R$ in 11.8 times $(P=0.01)$. 


\section{Conclusions}

1. The results of the conducted study indicate that multivariate logistic regression analysis allows determining the risk factors for preterm labor. Among the established prognostic markers for spontaneous development of preterm labor, the complex assessment of age, BMI and hormonal profile contain the most comprehensive information.

2. The findings suggest that dependent risk factors for preterm birth include: the level of progesterone lower than $139.5 \mathrm{ng} / \mathrm{ml}$, cortisol less than $577.9 \mathrm{ng} / \mathrm{ml}$, BMl less than $24 \mathrm{~kg} / \mathrm{m}^{2}$ and maternal age of over 25 years. Independent factors should include maternal age of over 35 years, the level of insulin above $31.36 \mathrm{ng} / \mathrm{ml}$ and progesterone less than $247.8 \mathrm{ng} / \mathrm{ml}$.

3. Considering the study results, high specificity and sensitivity of the proposed multivariate models, it would be appropriate to include measurements of progesterone, insulin and cortisol levels in the standard examination complex for pregnant women from 22 to 34 weeks of gestation. It will enable the identification of a risk group for preterm labor and implementation of timely prevention.

Prospects for further research. A comprehensive assessment of biochemical markers taking into account the psycho-emotional state of pregnant women with PD is going to be conducted.

\section{Funding}

The research was carried out within the framework of research work of the Zaporizhzhia State Medical University "Scientific substantiation of the influence of non-medicamentous and medical methods of treatment of pregnant women on reduction of obstetric and perinatal complications" (state registration number 0110U000909).

Conflicts of interest: authors have no conflict of interest to declare. Конфиікт інтересів: віАсутній.

Надійшла Ао редакції / Received: 27.07.2019

Після Аоопрацювання / Revised: 14.08.2019

Прийнято Ао Аруку / Accepted: 05.09.2019

Information about the authors:

Shevchenko A. O., MD, Assistant of the Department

of Obstetrics and Gynecology, Zaporizhzhia State Medical

University, Ukraine.

Krut Yu. Ya., MD, PhD, DSc, Professor, Head of the Department of Obstetrics and Gynecology, Zaporizhzhia State Medical University, Ukraine.

\section{Відомості про авторів:}

Шевченко А. О., асистент каф. акушерства та гінекології, Запорізький державний медичний університет, Україна.

Круть Ю. Я., А-р меА. наук, професор, зав. каф. акушерства та гінекології, Запорізький державний медичний університет, україна.

\section{Сведения об авторах:}

Шевченко А. А., ассистент каф. акушерства и гинекологии, Запорожский государственный медицинский университет, Украина.

Круть Ю. Я., А-р меА. наук, профессор, зав. каф. акушерства и гинекологии, Запорожский государственный медицинский университет, Украина.

\section{References}

[1] Serov, V. N., Sidelnikova, V. M., Agadzhanova, A. A., \& Tetruashvili, N. K (2003). Rannie poteri beremennosti - novoe ponimanie gormonalnyh narushenij [Early pregnancy losses - a new understanding of hormonal disorders]. Russian Medical Journal, 11(16), 907-908. [in Russian].

[2] Zhuk, C. I., \& Chechuga, S. B. (2008). Sovremennye aspekty patogeneza, diagnostiki i lechenija gipergomocisteinemii u zhenshhin $s$ nevynashivaniem beremennosti [Modern concepts of the pathogenesis, diagnosis and treatment of hyperhomocysteinemia in women with miscarriage]. Women's doctor, 5, 14. [in Russian].

[3] Di Renco, D.K. (2008). Sovremennyj vzgljad na vedenie prezhdevremennyh rodov [Modern view on management of preterm birth]. Women's doctor, 4, 41. [in Russian].

[4] Usanov, V. D., Shtah, A. F., Ishkova, M. V., Magdeeva, N. I., Popova, O.A., \& Timshin, A. V. (2010). Akusherskie aspekty prezhdevremennyh rodov. Sovremennye predstavlenija [Obstetric aspects of preterm birth. Modern views]. University proceedings. Volga region, 1(13), 120-132. [in Russian].

[5] Hodzhaeva, Z. S. (2010). Taktika vedenija spontannyh prezhdevremennyh rodov s pozicij dokazatelnoj mediciny [Management tactics of spontaneous preterm birth from the point of view of evidence-based medicine]. Gynaecology, 2, 12-16. [in Russian].

[6] Slattery, M., \& Morrison, J. (2002). Preterm delivery. The Lancet, 360(9344), 1489-1497. doi: 10.1016/s0140-6736(02)11476-0

[7] Hamilton, B., Martin, J., Ventura, S., Sutton, P., \& Menacker, F. (2006) Births: Preliminary Data for 2007. National vital statistics reports: from the Centers for Disease Control and Prevention, National Center for Health Statistics, National Vital Statistics System. CDC, 54. 1-17.

[8] Goldenberg, R., \& Rouse, D. (1998). Prevention of Premature Birth. New England Journal Of Medicine, 339(5), 313-320. doi: 10.1056/ nejm199807303390506

[9] McCormick, M. (1985). The Contribution of Low Birth Weight to Infant Mortality and Childhood Morbidity. New England Journal Of Medicine, 312(2), 82-90. doi: 10.1056/nejm198501103120204

[10] Zhukovec, I. V., \& Zarickaja, Je. N. (2012). Sintez steroidnyh gormonov vo vremja beremennosti [The synthesis of steroid hormones during pregnancy]. Yakut Medical Journal, 2, 96-98. [in Russian].

[11] Andréen, L., Nyberg, S., Turkmen, S., van Wingen, G., Fernández, G. \& Bäckström, T. (2009). Sex steroid induced negative mood may be explained by the paradoxical effect mediated by GABAA modulators. Psychoneuroendocrinology, 34(8), 1121-1132. doi: 10.1016/j.psyneuen.2009.02.003

[12] Schiller, C., Meltzer-Brody, S., \& Rubinow, D. (2014). The role of reproductive hormones in postpartum depression. CNS Spectrums, 20(1), 48-59. doi: 10.1017/s1092852914000480

[13] Stopińska-Głuszak, U., Wasilewska-Dziubińska, E., Słowińska-Srzednicka, J. (2008) Progesteron - neurosteroid syntetyzowany w układzie nerwowym [Progesterone - neurosteroid synthesized in nervous system.]. Postępy Nauk Medycznych, 3, 154-158. [in Polish].

[14] Ananth, C., Ananth, C., \& Vintzileos, A. (2006). Epidemiology of preterm birth and its clinical subtypes. The Journal Of Maternal-Fetal \& Neonatal Medicine, 19(12), 773-782. doi: 10.1080/14767050600965882

[15] Spiridonova, N. V., \& Melkadze, E. V. (2013). Sostojanie novorozhdennyh $u$ zhenshhin pri prezhdevremennyh rodah $v$ zavisimosti ot nalichija ugrozy preryvanija beremennosti v I, II, III trimestrah gestacii [The condition of newborns in women with preterm birth depending on a miscarriage risk during the I, II, III gestation trimesters]. Mother and Child. Proceedings of the XIV All-Russian scientific forum. (pp. 461 462). Moscow. [in Russian].

[16] Hassan, S., Romero, R., Vidyadhari, D., Fusey, S., Baxter, J., \& Khandelwal, M. et al. (2011). Vaginal progesterone reduces the rate of preterm birth in women with a sonographic short cervix: a multicenter, randomized, double-blind, placebo-controlled trial. Ultrasound In Obstetrics \& Gynecology, 38(1), 18-31. doi: 10.1002/uog.9017

[17] Behrman, R. E. (2007). Institute of Medicine (US) Committee on Understanding Premature Birth and Assuring Healthy Outcomes. Behrman, R. E., \& Butler, A. S. (Eds). Preterm Birth: Causes, Consequences, and Prevention. Washington, DC: National Academies Press (US). Retrieved from https://www.ncbi.nlm.nih.gov/books/NBK11362/ doi: $10.17226 / 11622$ 